\title{
Pirandello: Don Quijote or Don Chisciotti?
}

\section{Gaetano Cipolla}

In the last paragraph of Chapter $\mathrm{V}$ of his famous essay on Umorismo (1908), while analyzing the differences between so true a hero as El Cid and Cervantes' unlikely candidate Don Quijote, Luigi Pirandello suffered an interesting mental lapse (not entirely due to the haste with which the book was supposedly written), which has escaped the attention of the critics. Let us read the paragraph in question:

Ma Don Quijote? Coraggio a tutta prova, animo nobilissimo, fiamma di fede; ma quel coraggio non gli frutta che volgari bastonate; quella nobiltà d'animo è una follia; quella fiamma di fede è un misero stoppaccio che egli si ostina a tenere acceso, povero pallone mal fatto e rappezzato, che non riesce a pigliar vento, che sogna di lanciarsi a combattere con le nuvole, nelle quali vede giganti e mostri, e va intanto terra terra, incespicando in tutti gli sterpi e gli stecchi e gli spuntoni, che ne fanno strazio, miseramente. ${ }^{1}$

I am not concerned with the significance of Don Quijote in the context of Pirandellian humor. For the moment, I am primarily interested in Pirandello's characterization of the Knight of La Mancha. That part that deals with Don Quijote's personal traits, i.e., his great courage, the nobility of his soul, his unshakable faith in the codes of chivalry, his madness, the opposition between nobility of ideals and blindness in the face of reality, present no difficulties of any kind. They are the traits that one normally associates with Don Quijote. However, when Pirandello refers to specific events in the life of the Knight, a problem arises. In the paragraph quoted, two such events are mentioned. The first one, "quel coraggio non gli frutta che volgari bastonate," while remaining general enough to be a cliché of quijotism, is anchored firmly onto an actual event in the life of the Spanish hidalgo. It is a Quijotian as well as Quijotic event, that is, an event 
described by Cervantes in his novel, as well as an event that obeys the rules of behavior under which Quijote operates. The episode from which the remark was derived can be easily identified. It is the episode (Part I, Chapter IV) in which Don Quijote receives a merciless beating at the hands of a young muleteer. It will be recalled that the Knight had demanded from a group of merchants travelling in a caravan that they acknowledge Dulcinea's superior beauty in comparison with all other women. When the merchants refused, Don Quijote threatened mayhem and began a murderous charge against them. Unfortunately, Rocinante stumbled and the Knight landed on the ground, where he remained, unable to move because of his heavy armor, becoming thus an easy adversary to the muleteer. Pirandello's comment is, therefore, an accurate assessment of the event.

As we continue reading the paragraph, we note that Pirandello's words have become highly metaphorical and do not seem to refer to the text of the Quijote. Certainly, when the playwright refers to a "badly made and patched up balloon that cannot catch the wind," no one would associate such an image with the Cervantian text. However, when Pirandello begins to describe the dream to wage a battle against the clouds in which the Knight sees giants and monsters, as he runs on the ground bumping into all sorts of obstacles which tear his flesh to pieces, the passage cannot be dismissed as an extended metaphor of Quijotic behavior. We realize that we are dealing with another specific episode from the life of the Spanish hidalgo. The description is far too precise to be a simple metaphor. The playwright's attention is focused on an event that seems to unfold right before his eyes. He follows the Knight as he discerns giants and monsters in the clouds, he sees him falling and rising again, he recognizes the exact nature of the obstacles thwarting the progress of the Knight ("Sterpi, stecchi e spuntoni.") and he observes with a lingering glance how his flesh is being torn wretchedly. Such detailed description would not have occurred, it seems to me, unless the author were following in his mind's eye a specific episode. And this is where the difficulty lies. Where did this episode take place in the Cervantian novel?

My attempts to find the event that may have been the matrix for Pirandello's account have been fruitless. There is nothing even remotely similar to the episode just described in the Don Quijote. The Knight fights against wind mills; he has an encounter with some wineskins; he fights against a Basque, but there is no epi- 
sode in which the knight engages or dreams of engaging in a battle against giant-hiding clouds. There is a reference to a cloud in which the magician Freston travels, but it is only a passing image that remains undeveloped.

The question that must be answered is: "Where does the episode come from, if it's not of Cervantian derivation?" Presumably, Pirandello could have invented a new episode. After all, just a few pages preceding the quotation with which we began, the playwright asserted categorically not only the independence of the character from the author who created it but the reader's right to imagine any given character in situations which had not occurred even to the author:

Quando un poeta riesce veramente a dar vita a una sua creatura, questa vive indipendentemente dal suo autore. Tanto che noi possiamo immaginarla in altre situazioni in cui l'autore non pensò di collocarla, e vederla agire secondo le intime leggi della sua propria vita, leggi che neanche l'autore avrebbe potuto violare. ${ }^{2}$

In order to create a new episode, Pirandello would have had to remain faithful to the inner laws of behavior under which Don Quijote operated. The episode that we are examining is eminently Quijotic. Indeed, Pirandello's obeisance to the rules of Cervantian imagination is probably responsible for critics' failure to notice that the episode does not exist in the Cervantian novel, in spite of the fact that many scholars well acquainted with the Don Quijote must have been puzzled by their inability to locate it in the context of the novel.

At this point, I would like to suggest a scenario that could clarify the situation. The episode we have been discussing was not invented by Pirandello. It was derived from a poem of a fellow Sicilian of another century, whose work Pirandello seemed to know quite well. ${ }^{3}$ I am referring to Giovanni Meli (1740-1815), the most accomplished poet who ever wrote in Sicilian. The Pirandellian description is in reality a condensation of a very long episode (almost 30 octaves) from Meli's ambitious mock epic, Don Chisciotti e Sanciu Panza, a poem of twelve cantos and a "Vision," written in Sicilian "ottava rima," between 1785 and $1786 .{ }^{4}$ In the Sicilian poem, the archetypal couple of Don Chisciotti and Sanciu Panza retain their ancient physiognomies but express a different poetic sensibility as well as changed political, economic, and social conditions. 
There can be very little doubt that Pirandello was actually thinking of the Melian episode when he wrote the paragraph in question. For the sake of brevity, let us compare the two accounts. In Canto V of the Don Chisciotti, the Knight was startled from a moment of pensiveness by the sudden appearance of a "giant" running across the side of a mountain:

Quann'eccu un gran giganti smisuratu chi pri dda costa rapidu curría. ${ }^{5}$

Immediately he called Sanciu to bring him his armor, but the squire, realizing quickly that the "giant" was only a reflection of a cloud passing over head, began pondering the misery of man who frets needlessly and without cause:

Si cirnemu e si jamu esaminannu

li causi di li còluri e li rissi

truvamu chi sti mostri e sti giganti

sunnu nuvuli ed umbri tutti quanti. ${ }^{6}$

The giants and the monsters named here are the same as the ones Pirandello recalled. Don Chisciotti did not listen to his squire's advice because he claimed to have more experience with evil things and with the various disguises employed by witches. Thus he began a mad chase after the "giant":

Eccu s'abbía versu lu giganti,

e mustrannu ch'è mastru di la guerra,

isa lu scutu di la testa avanti:

ora s'inquarta, ora si abbassa a terra,

ora stenni lu vrazzu fulminanti. ...?

While Don Chisciotti thought that he had discovered the weakness in the giant's defense, a fly flew into one of his eyes to seek refuge there from the pursuit of a horse fly that had . . . amorous intentions. The Knight was forced to halt the chase for a moment but as soon as he was rid of the fly, he resumed his race against the clouds. In his haste to catch up with the giant, Don Chisciotti is utterly mindless of the obstacles that stand in his way. Such determination has predictable consequences:

Quantu voti cadiu, quanti s'alzau

Quantu contusioni in vrazza e rini, 
Quantu macchi e piraini affruntau. . .

Quantu voti la carne si sfardau,

Quantu sangu chiuviacci da li vini. ...8

Finally the Knight caught up with the giant, so he thought, and struck him with a mighty blow. In reality his sword hit a large rock sending pieces of it all over the Mediterranean Sea.

The correspondences between Meli's episode and Pirandello's brief description could not be more precise. The only variant is represented by Pirandello's reference to Don Chisciotti's dreaming of waging a battle against clouds. This detail may seem insignificant, but it may have been the catalytic agent which activated the recollection of the Melian episode. Pirandello had probably intended to give another example of Quijotic behavior. In fact, the sentence, "sogna di lanciarsi a combattere contro nuvole . . . " is vague enough to be a cliché of Quijotism. At this point in Pirandello's mind Don Quijote was not fighting against any specific cloud, but rather "clouds" in a general sense, that is, insubstantial things, ghosts of his imagination, shadows. However, the image of the clouds as a possible antagonist of Don Quijote probably triggered the recollection of the Melian episode which Pirandello proceeded to describe accurately and very likely without realizing that a superimposition of images from two different sources had occurred. It is difficult to say whether Pirandello may have realized, at some later time, the unconscious substitution. It cannot be denied, however, that the mental lapse which permitted the intrusion of a Melian adventure in a Cervantian context, actually occurred. This fact may be interpreted as another affirmation of Pirandello's high regard for the work of his fellow Sicilian with whom he shared not only his native idiom but a common attitude toward the world and toward writing which can be summed up in one word: "Umorismo."

St. John's University

\section{NOTES}

1 Saggi, poesie, scritti varii, Vol. V (Milano: Mondadori, 1960) p. 104.

2 ibid., p. 101.

3 In his essay on "Umorismo," Pirandello devoted a short paragraph to Giovanni Meli during the discussion of Italian humorists. The paragraph clearly demonstrates not only Pirandello's knowledge of Meli's work but also his acquaintance with the critical literature on his fellow Sicilian, as can be seen in his dismissal of G. Carducci's characterization of Meli's poetry as "arcadia superiore," 
and in expressing an original view of the Sicilian Abbot as a humorist: "Sul serio poi l'Arcoleo crede che nella nostra letteratura dialettale non ci sia altro che spirito comico? Egli è siciliano e certamente ha letto il Meli, e sa quanto sia ingiusto il giudizio di 'Arcadia superiore' dato della poesia di lui, che non fu sonata soltanto su la zampogna pastorale, ma ebbe anche tutte le corde della lira e si espresse in tutte le forme. Non c'è vero e proprio umorismo in tanta parte della poesia del Meli? Basterebbe citar soltanto 'La cutuliata' per dimostrarlo!

Tic tic . . . chi fu? Cutuliata." (Op. cit., p. 117)

It is interesting to point out that Pirandello was relying on his memory for the title and for the line he quoted, both of which are incorrectly given. The correct title of the poem is "Lu specchiu di lu disingannu o sia la cugghiuniata" and the line in question reads "ticchi ticchi, finíu ... cugghiuniata." The poem, however, is a perfect embodiment of Pirandello's definition of humor as "sentimento del contrario."

4 This mock epic, which needs to be re-evaluated, is being translated into English verse by the present author. A good portion of Canto I will appear in Italian Quarterly in 1984. The quotations from the Don Chisciotti come from Opere, a cura di Giorgio Santangelo, Vol. Il (Milano: Rizzoli, 1968).

5 Canto V, 49: This excerpt and those that follow are my translations:

When there appeared a huge and boundless giant

running in haste along the mountain side.

6 Canto V, 52:

If we but sift and carefully regard

the causes of all wrathful acts and riots,

we will discover that such monsters and

such giants are just clouds and empty shades.

7 Canto V, 55:

Behold! He started moving toward the giant

and showing he was master of warfare,

he raised his armor high before his head.

At first he parried, then he bent to the ground.

Then he extended his most dreadful arm. . . .

8 Canto V, 63:

So many times he fell and rose again,

So many bruises on his arms and sides,

So many thorns and brambles did he face,

So many times his flesh was torn apart,

and so much blood rained out of his poor veins! 